\title{
Patriarchal Domination and Inequal Power Structure in Silence! The Court Is In the Session
}

\author{
Arka Pramanick \\ M.a, the university of burdwan, govt. Assistant teacher of engish in chhotosarsa junior high school
}

\begin{abstract}
Since the question of subjugation of woman in patriarchal power structure is crucial in modern culture, Indian as well as Western dramatists have used the stage to expose gender discrimination in patriarchy and how women fight against this injustice. The purpose of this research paper is to study patriarchal domination and inequal power structure in Vijay Tendulkar's play 'Silence! The Court is in the Session'.
\end{abstract}

Keywords: injustice, womanhood, inequality, patriarchy, sadism, exploitation.

\section{Introduction}

In patriarchal culture, power is equated with aggression and masculinity; weakness with compassion and feminity. Women are supposed to bear male oppression silently and meekly. Where they fail to do so, they are branded as ' loud' hysterical, crazy and punished. Naturally the politics for survival amidst the dominant male power for woman is a perennial, open-ended problem for study. Here comes the term "feminism" which denotes a movement in politics and aesthetics which deals with women's rights and their conscious struggle against the oppressive dominance of patriarchy. This advocacy of women's rights on ground of equality of the sexes gained momentum since the publication of Simone de Beauvoir's The Second Sex (1949). Beauvoir holds social conditioning responsible for the othering of women in patriarchy and argues that while sex is biological, gender is social construct: "one is not born a woman, rather becomes a woman" [1]. Later on Kate Millet insists that the roots of women's oppression are deeply buried in gender system of patriarchy. This ideology is weak as it separates women from the mainstream rather than integrating them into it. Radical feminism sees the oppression of women as fundamental and the most basic form of oppression. All other forms of oppression stem from male dominance. The purpose of this oppression is to obtain psychological ego satisfaction and strength and self-esteem.

Since this question of subjugation of woman in patriarchal power structure is crucial in modern culture, Indian as well as Western dramatists have used the stage to expose gender discrimination in patriarchy and how women fight against this injustice. The purpose of this research paper is to study patriarchal domination and inequal power structure in Vijay Tendulkar's play 'Silence! The Court is in the Session'.

Silence! The court is in session (1967), the first Tendulkar's play to become part of the New Indian Drama phenomenon of the sixties and the first significant modern Indian play in any language to centre on woman as protagonist and victim. With its production Tendulkar became the center of a general controversy. He had already acquired the epithet of "the angry young man" of Marathi theatre but now he was definitely marked out as a rebel against the established values of fundamentally orthodox patriarchal society. The play is the milestone in dramatic career of Vijay Tendulkar and so Mr. N.S. Dharan writes :

"Vijay Tendulkar's plays can be said to fall into two distinct groups, namely, Pre-silence plays and Post-silence plays. In the plays that Tendulkar wrote prior to Silence! The focus, by and large, is on the sufferings of the middle class man living in an urbanized, industrialized society.....Silence!, however, marks a change in Tendulkar's attitude towards his favourite subject, that is, the middle class man. For the first time in his dramatic career he began to look into the psyche of his subject and focus his attention on the ugliness he detected therein." [2]

The play is based on a short story by Friedrich Dürrenmatt(1921-1990). The short story "DiePanne" written in 1956 is available in an English translation titled "Traps". Silence is originally a marathi play named, "Shantata! Court Chalu Ahe" which has been translated by Priya Adarkar seemingly in an accurate manner and is the part of the selection Vijay Tendulkar : Five Plays (Oxford). The stimulus for Silence! The Court is in Session came from a real incident for the writer. Tendulkar met an amateur group which was on its way to stage a mock-trial in Vile Parle, a suburb of Bombay. While overhearing their conversation, the outline of a play began taking shape in the writer's mind and resulted in the creation of Silence! The Court is in Session. The play was written for Rangayana at the instance of Arvind and Sulabh Deshpande and was first performed in March 1971 in Madras. In the play Tendulkar presents the futile struggle of a woman in the male-dominated society of post-Independence India. When asked in an interview: "This play is a caustic satire on the social as well as 
justice.... The mental agony suffered by the girl throughout the play is in no way less than the legal punishment. Is that all you wished to convey or something more?" Tendulkar said:

"This is exactly what I had in mind. If I say anything else now, that will be an after-thought. An undaunted girl of Benare's make-up could have, besides defending herself, made a counter-attack, tearing to pieces the dos and don'ts of the selfish society. Had I shown her aggressive that would have been attitude, not hers? Otherwise also the playwright should only suggest leaving the rest to the viewers."[3]

The play in three acts deals with the lives of ordinary people in a small town. Coming from diverse backgrounds, around ten characters are engaged in a group activity. They are members of "The Sonar Moti Tenement (Bombay) Progressive Association (SMTPA). This is a socially committed group whose prime objective is to facilitate awareness around important issues affecting the community or the world. The theatrical group has come to a village to perform a mock-trial of President Johnson for producing atomic weapons. Leela Benare, the central character of this group possesses a natural lust for life and a spontaneous joie de vivre, who ignores social norms and dictates -

"My wishes are my own...I'll do what I like with myself and my life! I'll decide"

At the beginning we find her as a self-assertive and deeply committed to her job of teaching. Her first song " Oh, I have got a sweet heart " also shows her loving nature- she wants a loving, caring lover. She is happy to take part in a play concerning the trial of President Johnson for manufacturing atomic weapons. But she is unconscious that the mock trial they propose to perform will be her real trial. Yet there are latent hints of her suppressed sufferings-

"They're holding an enquiry, if you please! But my teaching's perfect. I've put my whole life into itI've worn myself to a shadow in this job! Just because of one bit of slander, what can they do to me? [...] My life is my own." (Silence, pp.4-5).

This voice of self assertion, this voice of individuality endows Benare with the identity of 'a new woman' emerging against the coercive attacks of patriarchy.

As the play progresses, we see, an actor Rawte is absent ( Prof Damle who is to play the keyrole in the play is also absent) and so Samant, the villager who has come to get acquainted with the group and to show the hall where the performance will take place, is asked to to play the part of intricacies of the court-scene. To train Samant how to act the part of a witness the other members of the group decide to arrange another mock courtscene. In the disguise of the so-called "game" which is meaningfully set in the form of a mock-trial, Miss Benare's private life is exposed and publically dissected, revealing her illicit love affair with professor Damle, a married man with a family, which has resulted in her pregnancy. Professor Damle is significantly absent at the trial denoting his total withdrawal of responsibility, either social or moral, for the whole situation into which he had landed Miss Benare. This tragic and bottle neck like situation reminds us the audience of Banavari Devi, Nina Sahni, Tasneem Sheikh Suhail,Delhi model Jessica Lal and Nirbhaya and claims Vijay Tendulkar as a man of relevance to the contemporary society, where the practices like - eve teasing, whistling at girls, bottom pinching and are common phenomenon among Indian youngsters, apart from big incidents like gang rapes and murders. During the trial, prof Damle is summoned merely as a witness while Benare remains the prime accused as the unwed mother of his illegitimate child. Interestingly, the accusation brought against her at the beginning of the trial - that of infanticide - turns into the verdict at the conclusion. Smita Paul comments in her book Theatre of Power:

"The women characters in Tendulkar's theatre undergo a series of sufferings and tortures as the victims of the hegemonic power-structure. In the male- dominated theatre-world they are constantly being 'other-ed'. In Silence! the focal point of interest lies is the struggle between women like Benare and her antagonists headed by the orthodox Kashikar and his associates".[4]

The play thus depicted the tragedy of an individual victimized by male dominated society. The female protagonist becomes the victim of sadism of his male counterparts. Benare is cross-examined in the mock court with full mockery. All the other characters like witnesses Mr. Gopal Ponkshe, Mr. Karnik, Rokde, Samant, Counsel for the defense and counsel for the crown Mr. Sukhatme and Judge, Mr. Kashikar and his wife Mrs. Kashikar all behave in a way of mockery. Benare is summoned merely as a witness while she remains the prime accused as the mother of an illegitimate child and having illicit relations with so many persons. The frustrated male members of the society try to subjugate women to prove their power and superiority in the social hierarchy. They praise motherhood with bombastic phrases but try to destroy Benare's infant in the womb. Benare is stigmatized and sacked from her job. But Prof. Damle, the man responsible for her condition, escapes scot-free for he is a male. And Sukhatme, the brief less barrister, puts the final nail in the coffin of womanhood:

SUKHATME. [...] No allowance must be made because the accused is a woman. Woman bears the grave responsibility of building up the high values of society.' Na stri swatantryamarhati.' 'Woman is not fit for independence.'. (Silence, p.71)

Thus the imaginary mock-trial, 'the play-within- the play' gradually grows into a serious affair and the latent sadism of the characters come to the fore. What is more disturbing is that Mrs Kashikar, the elderly 
childless woman, who should have supported Benare, gangs up with the male members and severely criticizes her. As a witness she heinously attacks professionally successful women:

"MRS KASHIKAR. [...] That's what happens these days when you get everything without marrying. They just want comfort."

Thus Benare who bubbles with over-confidence in the beginning turns into a victim of social injustice at the end. She represents the working class women who wants to lead a liberated life. Though she is a victim of incest, it is not in the main focus as it is referred to by way of reflection by Benare herself. She is robbed of her virginity when she hardly fourteen years old. The focal point of the play is the violent response of the male dominated society to ore-marital relationship and motherhood. The mock - trial holds a mirror to our social response to such things. It is pre-eminently male biased. What is wrong, immoral for a woman is not so far a man. Benare is the accused and not Prof. Damle. Subha Tiwari in her article "Silence! The court is in Session. A strong social commentary" states "The whole responsibility of morally upright behaviour is bulldozed on

women. Men are by nature considered to be willful, wild, childish, innocent and mischievous. Their sins are no sins at all. The society has a very light parental and pampering sort of attitude when it comes to sexual

offences of men. In case of women the iron rod gets hot and hotter. No punishment is actually enough for such a woman. There is no respite, no shade and no soothing cushion for a sinning woman. She must be stained and abandoned. Her femininity, her needs, her very existence must be ignored or rather destroyed. She must be cornered and brutally killed both in physical and psychological senses. This play is about the pathetic position of women in the male dominated Indian world." The comment proves to be a right one as we see before passing the final verdict on Benare, she is given ten seconds to defend her case. The motionless Benare stands up erect and says, "Yes, I have a lot to say" (Silence, p.72). Then follows a long monologue in which Benare expresses her zest for life and tells how she is deprived of her wishes:

BENARE. [...] My life was a burden to me. [Heaving a great sigh] But when you can't lose it, you realize the value of it. [...]There's great joy in a suicide that's failed. It's greater even than the pain of living. [...] I swallowed that poison, but didn't even let a drop of it touch them! [...] I cried inside, and I made them laugh. I was cracking up with despair, and I taught them hope. (Silence, pp.72-73)

Benare hurls her denigrating attack against patriarchy in this monologue:

BENARE. [...] These are the mortal remains of some cultured men of the twentieth century. See their faces-how ferocious they look! Their lips are full of lovely worn-out phrases! And their bellies are full of unsatisfied desires. (Silence,p.74).

In the final verdict Benare is equated with 'criminals and sinners' and the court orders that she should live but the child in her womb should be destroyed. One may say that her monologue at the end is reminiscent of Nora Helmer's declaration of independence in Ibsen's The Doll's House. What strikes us most is that unlike Nora, Benare stands tall in her all utter psychological harassments. According to P. Obula Reddy and P. Pramila Devi, Benare, the principal character in the play is as sprightly, rebellious and assertive as the heroine of Shakespeare romantic comedies - of course. Benare is lovely spark from the thunder bolt of Tendulkar. She is a new woman pleading for freedom from the social norms. (Reddy and Devi 36). This is suggestive of Benare's last speech when she breaks her silence and speaks passionately about conspiracy against her.

Vijay Tendulkar also presented the court by converting the accusation into the verdict. The mock-trial ends up with an interruption by a visitor reminding them of their being late in the show. This interruption brings them back from illusion to reality. But Benare remains in the same condition engrossed in thought for she is overtaken by the reality implied in the illusion. Her reality is different from others. Parrot in the play is a powerful symbol of illusion of her own self and sparrow represents her reality. The green cloth parrot is also a symbol of the foetus taking human shape in her womb. But she would be losing in the due course of time in deference to the enjoinment of the fustian value holders of society.

The character of Ms. Benare also reminds us to various female characters depicted by Arundhati Roy, Shashi Deshpande and Anita Desai in their books. These writers also exposed the suffering of the women at the hands of the male dominating society. The mock - trial holds a mirror to our social response to moral values. Sex is a private affair in one's life. But there certain social and moral values attached to it. In fact pre-martial or post-marital sexual relations are condemned in Indian society. The social rules in practice are more- strict for women than for men. Tendulkar throws light on this hypocrisy of the patriarchal society that excuses men and punishes women for the same offence. Benares maternal uncle nowhere appears as an accused for committing incest with her. Similarly Prof. Damle is merely a witness in the trail of the case, where as Benare is an accused of the society of law. She has done no offence in the eyes and the law, but she has violated the social taboo. This false position of the men in the court, as he has done any infanticide, prompts them to an illegal wedding of the judicial laws and social laws to prosecute the woman challenging men's authority. A feminist would discern a realistic depiction of the society and the court biased against the women as they are dominated by men. In fact we see all the male characters like Ponkshe (the science student), Sukhatme( the lawyer), Karnik(the theatre actor), Balu Rokde and Mr. Kashikar seem to be presenting thr patriarchal forces of society that cut the wax- 
wings of Ms. Benare and pathetically subjugates her. Though Samant seems to be quite a non-chauvinistic character at the initial stage, eventually he is also transformed into a amale chauvinist. Ponkshe and Karnik are the other two catalysts who have their active role in the plot against Benare. When Benare goes into the inner room to wash her face, Karnik takes Ponkshe aside and indicating the inner room into which Benare has just gone, tells him if he knows anything about her: "About her, About Miss. Benare. Rokde told me". The stylistic gimmicks used by Ponkshe and Karnik sometimes speak a lot louder than the words they actually speak. As witness their technique is not to argue the case but to present the issues. These two people represent the educated elite in the society, who have to demand for 'order of proof' as yardstick before asking the jury to measure the complaint. But these people lack the logical order of proof for their expert testimony. Even Mrs. Kashikar, being herself a woman, supports the patriarchal domination and has damaging view against Benare. During the session of the entire "mock-trial" Mrs. Kashikar never misses an apportunity to insinuate her venomous comments directed at Benare as she is extremely envious of Benare's boundless independence Herself, suffering from a persecution complex on account of her barreness, and her abject dependence on her husband. She is utterly spiteful of Benare. In the closing act, Tendulkar gives Mrs. Kashikar ample opportunity to torture Benare with a view to exposing a discontented woman's irrepressible malevolence against a superior, successful being. For instance, she stops Benare getting out of the torture "where do you think you're going? The door's locked! Sit down!". All these actually promotes the notorious inequal power structure of male dominated society where man has all the rights to be sinful in the society. All the rights to are reserved specially for him. On the other hand, a woman must be deserted, ignored, thrown away and should be punished for her sins.

Tendulkar poses another important question to the legal provisions of women in India. If the child is a legitimate one, the father is honoured with the guardianship of the child. But if the child is illegitimate the mother is the guardian, and she alone has to bear the stigma and humiliation of every day social pin-pointing as well as the responsibility of bringing up the child. The law makes no distinction between legitimate and illegitimate child when it imposes on the father an obligation to maintain children6. But if it is under the guardianship of the mother, the man escapes everyday disgrace by merely paying the maintenance amount, at the most! To put it briefly, 'the law recognizes the patriarchal system of family in which father supreme." [7] By showing this inequality in case of justice Tendulkar actually has tried to expose the vagueness of Indian justice.

In Silence, Tendulkar actually directs his criticism against the hypocritical male attitude in Indian society where a woman is quite suppressed and any small attempt by a woman for her freedom is highly deteriorated. Though Tendulkar is not a self-acknowledged feminist, he goes with the feminists in voicing women's concern, their sensibility and their subjugation as well as their protest. We can conclude with what Tendulkar himself says : "As a social being, I am against all exploitation and I passionately feel that all exploitation must end ."

\section{References}

[1]. Beauvoir, Simone de, The Second Sex, Trans. And ed. H.M Parshley, (London: Penguin, 1974).

[2]. Dharan, N.S " "Vijay Tendulkar : A unique writer".

[3]. Tendulkar, Vijay (1974): 'Silence! The Court is in Session', Translated by PriyaAdarkar, Five Plays, and Oxford University Press : New Delhi, p. vii.

[4]. Tendulkar, Vijay (1992): 'Silence! The Court is in Session', Translated by Priya Adarkar, Five Plays, and Oxford University Press : New Delhi, p.

[5]. Dharan, N. S. (1999). The Plays of Vijay Tendulkar. New Delhi: Creative Books.

[6]. Paul, Smita. (2010). Theatre of Power. Kolkata: Books Way Publishers \& Distributors.

[7]. Rahman, L. (2010). Tendulkar's Silence! The Court is in Session: A Study in Perspectives.

[8]. Ved Kumari. "Place of Women and Child in Guardianship" in Lotika Sarkar and B. Sivaramayya (eds), 'Women and Law: Contemporary Problems' Vikas PublishingHouse Pvt. Ltd. New Delhi ,1994, p.242.

[9]. Dass, Veena Noble (1994): 'Women Characters in the Plays of Tendulkar' New Directions in India, Dramaed. Sudhakar Pandey and Friya Barya, Prestige Books; New Delhi. 